\title{
Natural and Synthetic Mulching Materials for Weed Control in Immature Rubber Plantations
}

\author{
Ruwani Kalpana Jayawardana*, Rasika Hettiarachchi, Thushara Gunathilaka, \\ Anoma Thewarapperuma, Surani Rathnasooriya, Rangika Baddevidana, Helaru Gayan
}

Soils and Plant Nutrition Department, Rubber Research Institute of Sri Lanka, Agalawatta, Sri Lanka

Email address:

ruwanikal@hotmail.com (R. K. Jayawardana)

${ }^{*}$ Corresponding author

To cite this article:

Ruwani Kalpana Jayawardana, Rasika Hettiarachchi, Thushara Gunathilaka, Anoma Thewarapperuma, Surani Rathnasooriya, Rangika Baddevidana, Helaru Gayan. Natural and Synthetic Mulching Materials for Weed Control in Immature Rubber Plantations. American Journal of Plant Biology. Vol. 4, No. 4, 2019, pp. 114-117. doi: 10.11648/j.ajpb.20190404.20

Received: November 14, 2019; Accepted: December 4, 2019; Published: December 11, 2019

\begin{abstract}
Weed control is important during immature stage of rubber plantations particularly, before fertilizer application. Most of the chemicals are being restricted due to health and environmental concerns thus investigations on chemical free weed control methods are important. The effect of different natural and synthetic mulching materials on weed control was studied compared to manual weeding. Oil palm Empty Fruit Bunches (EFB) was used as natural mulch and shade net and polythene were used as synthetic mulch. Labor requirement in each treatment was evaluated. Effect of mulching on soil nitrogen content, $\mathrm{pH}$, organic carbon content and cation exchange capacity was also measured at three months and one year after treatment application. All the mulching treatments showed significant weed control compared to the control. Since, weed regeneration was observed in oil palm EFB treatment from ten weeks of its application, it was applied again in three months intervals. There were no weeds observed in both in shade net and polythene mulch treatments from four weeks of their application up to one year period. All the mulching treatments reduced labor requirement compared to the control. Organic carbon content was significantly improved by mulching while other soil parameters were not affected compared to the control. Shade net and polythene could be effectively used for weed management and they will be beneficial under labor shortage. Oil palm EFB is effective for weed control with labor saving and it has to be applied in three months intervals. However, there will be no environmental pollution with Oil palm EFB mulch as it is a natural waste material.
\end{abstract}

Keywords: Weed, Rubber, Mulching, Oil Palm, Shade Net, Polythene

\section{Introduction}

Weeds are unwanted and undesirable plants which compete for light, water, nutrients, carbon dioxide and space [1]. Weed management is more difficult but essential during immature stage of rubber (Hevea brasiliensis) plantations as there is lower shade and more space in the fields allowing more weed growth. In fact, weeding around the plant base before fertilizer application is highly important for the efficient use of fertilizer. Chemical control is most popular as it is easy and effective in weed control. However, at present chemicals have been restricted due to environmental and health concerns. On the other hand, excessive use of weedicides can cause the development of chemical resistance in weeds [2]. In such situation, investigation on alternatives for chemical weed control has become important.

Mulching around the plant base is an effective agronomic practice which has been already recommended by Rubber Research Institute of Sri Lanka (RRISL) for both weed control and soil conservation [3]. As rubber is a rainfed cultivation mulching would be important in moisture conservation too. Shah et al., reported that different mulching materials (natural or synthetic) have significant effect on weed suppression [4]. Covering or mulching the soil surface would prevent weed seed germination or physically suppress seedling emergence [5]. As a physical barrier, mulch cover reduces germination and nourishment of many weeds. Mulching reduces evaporation losses and facilitates more retention of soil moisture thus helps in controlling soil temperature 
fluctuations and improves physical chemical and biological properties of soil. It also reduces the deterioration of the soil by preventing runoff and soil erosion. In addition, mulch cover decreases nutrient lost by leaching particularly in sandy soils thus increases fertilizer use efficiency and diminishes environmental pollution. Natural or organic mulch materials are derived from plant and animal materials. They improve soil properties as they add nutrients to the soil and ultimately enhance the growth and yield of crops [6]. Synthetic mulching has become a popular practice worldwide in modern agriculture for weed control and moisture conservation [7]. The plastic materials used as mulch are polyvinyl chloride or polyethylene films [6]. Black plastic mulch film has become popular and very good results have been achieved particularly in arid and semi-arid regions [8]. Das et al., [9] and Purohit et al., [10] observed that use of polyethylene mulch in the field, increased the soil temperature especially in early spring, reduced weed problems, increased moisture conservation, reduced certain insect pest population, enhanced crop yield and increased soil nutrient use efficiency. Black polyethylene mulches are used for weed control in a range of crops under the organic system of crop production. The use of black polypropylene woven mulch is usually restricted to perennial crops [11].

Oil palm Empty Fruit Bunches (EFB) is the main solid waste material from palm oil extraction. The EFB as a lignocellulosic rich crop residue is suitable for many kinds of applications. It can be converted to bioplastic, pulp, source of enzymes, hydrogen and animal feed [12] but the demand for EFB by the industries is still limited. In Sri Lanka, it is dumped as a waste without taking any intimate use. However, the Oil palm EFB has a slow degrading property and can be used as a mulching material. It is rich in carbon, cellulose, hemicellulose, lignin and micro nutrients as well [13]. Moreover, it has been reported that the use of EFB is very effective as a mulching material for suppressing weeds in soil $[14,15]$.

In this study, Oil palm EFB as a natural mulching material and polythene and shade net as synthetic mulching materials were tested for weed control and subsequent weed regeneration around the rubber plant base in comparison to normal estate weed management practices without mulch. An evaluation on labor requirement for each treatment was also done.

\section{Materials and Methods}

\subsection{Experiment Site}

Experiment was conducted for immature rubber plantation which is at the second year of planting. Experimental site was located in Kaluthara District, Western province of Sri Lanka.

\subsection{Treatment Application}

Three different mulching materials were tested on weed control and weed regeneration compared to normal estate practices i.e allow naturals to grow and do manual weeding before the fertilizer application once in three months.

T1 - Control (Normal estate practices)

T2 - Oil palm EFB

T3 - Shade net

T4 - Polythene sheet

Treatments were arranged in Randomized Complete Block Design (RCBD) with four replicates consisting five plants per replicate. All the mulch materials were applied on naturals without weeding. Shade net and polythene sheet squares $(90$ $\mathrm{cm} \times 120 \mathrm{~cm}$ ) were laid and fixed around the plant base using wood sticks and ropes. A hole was made on the center of the square for the plant and a cut was made in one side of the square in order to insert the square into the plant base as in the Figure 1.

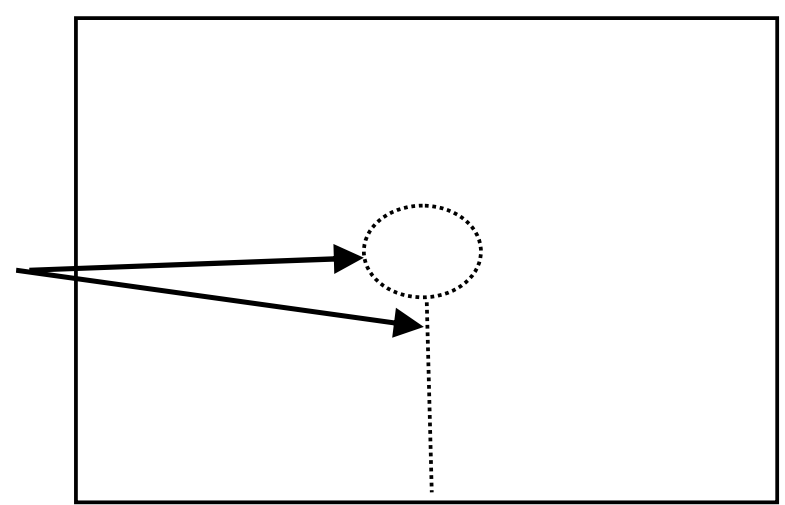

Figure 1. Diagram of polythene or shade net square applied as mulch Arrows are pointed on the dotted line indicating cut marks.

Oil palm EFB was applied around the plant base in a $90 \mathrm{~cm}$ radius circle to totally cover the soil once in three months period. Fertilizers were applied for all the treatments according to the RRISL recommendation [3].

\subsection{Observations and Measurements}

Percentage of weed death was observed in 2 weeks intervals and once $100 \%$ of weeds are dead, weed regeneration was observed in same intervals. Soil samples (three replicates per treatment) were collected from different treatments at 3 months and 1 year after the mulch application and were analyzed for soil nitrogen, $\mathrm{pH}$, Organic Carbon (OC) and Cation Exchange Capacity (CEC). For analyzing soil $\mathrm{N}$ content, dried and sieved ( $<2 \mathrm{~mm}$ of particle size) soil $(0.5 \mathrm{~g})$ was added with $1.0 \mathrm{~g}$ of Sodium Sulphate, $5.0 \mathrm{ml}$ of Selinium / Sulfuric solution $\left(1.0 \mathrm{~g}\right.$ of $\mathrm{Se}$ in 1 liter of $\left.98 \% \mathrm{H}_{2} \mathrm{SO}_{4}\right)$ and digested in $350^{\circ} \mathrm{C}$ for $210 \mathrm{~min}$, transferred into a $100 \mathrm{ml}$ volumetric flask and diluted up to $100 \mathrm{ml}$. The above sample was filtered by Whatman No.42 filter paper and $10 \mathrm{ml}$ from the filtrate was used for soil $\mathrm{N}$ analysis [16] using Kjeldhal distilation unit (UDK 129 Velp Scientifica Europe). Soil pH was measured by pH meter (pH1200 YSI inc. China) and soil organic carbon percentage was measured by Walkley and Black method [17]. Data were analyzed using SAS statistical software package - version 9.0 (SAS Inc. USA). At the end of one year experimental period, labor requirement in each treatment was evaluated and compared with each other. 


\section{Results and Discussion}

\subsection{Weed Control Under Different Treatments}

All the mulch treatments showed significantly higher weed control than the control treatment. Oil palm mulch treatment significantly controlled all the weeds by two weeks of mulch application. However, the weeds started regeneration at 10 weeks after oil palm treatment (Table 1). Control treatment showed weed regeneration in two weeks although there were no weeds initially. Both polythene and shade net treatments recorded significant control of weeds showing total weed control (no weeds) from 4 weeks of mulch application (Table 1).

Table 1. Percentage of weeds observed in each treatment during first three months of the experiment.

\begin{tabular}{|c|c|c|c|c|}
\hline \multirow{2}{*}{ Stage } & \multicolumn{4}{|c|}{ Percentage of weeds } \\
\hline & T1 Control & T2 Oil palm EFB & T3 Shade net & T4 Polythene \\
\hline Initial & $0.00 \mathrm{~b}$ & $100.0 \mathrm{a}$ & $100.00 \mathrm{a}$ & $100.00 \mathrm{a}$ \\
\hline 2 WAT $^{*}$ & $12.25 \mathrm{a}^{* *}$ & $0.00 \mathrm{~d}$ & $10.50 \mathrm{~b}$ & $8.00 \mathrm{c}$ \\
\hline 4 WAT & $21.00 \mathrm{a}$ & $0.00 \mathrm{~b}$ & $0.25 b$ & $0.00 \mathrm{~b}$ \\
\hline 8 WAT & $98.00 \mathrm{a}$ & $0.00 \mathrm{~b}$ & $0.00 \mathrm{~b}$ & $0.00 \mathrm{~b}$ \\
\hline 10 WAT & $100.00 \mathrm{a}$ & $12.25 b^{* *}$ & $0.00 \mathrm{c}$ & $0.00 \mathrm{c}$ \\
\hline 12 WAT & $100.00 \mathrm{a}$ & $23.25 b$ & $0.00 \mathrm{c}$ & $0.00 \mathrm{c}$ \\
\hline
\end{tabular}

Means with the same letter in each row are not significantly different at $\mathrm{p}<0.05$. ${ }^{*}$ WAT $=$ Weeks After Treatments. $* *$ Stage of Weed regeneration.

However, it should be noted that there was creeping cover crop (Mucuna bracteata) growing on the surface of polythene and shade net from 6 weeks period but these creepers were not penetrated and grown under the mulch and they could be removed with less effort and less labor in three months intervals (Table 2 shows requirement of labor).

Table 2. Calculated labor requirement in each treatment during the first year of mulch application and predicted labor requirement for five years.

\begin{tabular}{|c|c|c|c|c|}
\hline Stage & T1 control & T2 oil palm EFB & T3 shade net & T4 polythene \\
\hline Initial treatment application & $07 /$ ha & $04 / \mathrm{ha}$ & $10 /$ ha & $10 /$ ha \\
\hline At 3 months & $07 /$ ha & $04 / \mathrm{ha}$ & $02 / \mathrm{ha}$ & $02 /$ ha \\
\hline At 6 months & $07 /$ ha & $04 / \mathrm{ha}$ & $02 / \mathrm{ha}$ & $02 /$ ha \\
\hline At 9 months & $07 /$ ha & $04 / \mathrm{ha}$ & $02 / \mathrm{ha}$ & $02 /$ ha \\
\hline At 12 months & $07 /$ ha & $04 / \mathrm{ha}$ & $02 / \mathrm{ha}$ & $02 /$ ha \\
\hline Total labor required / first year * & $35 /$ ha & $20 /$ ha & $18 / \mathrm{ha}$ & $18 / \mathrm{ha}$ \\
\hline Calculated total labor required for first 5 years $* *$ & 140/ha & $80 /$ ha & $48 /$ ha & $48 /$ ha \\
\hline
\end{tabular}

*Calculations have been done considering plant spacing $=510$ plants $/$ ha, manual weeding capacity $=70$ plants by 1 labor day. $* *$ With predictions that shade net and polythene will survive for 5 years with no damages and natural mulches will be applied in 3 months intervals continuously.

\subsection{Soil Properties Under Different Treatments}

There were no significant difference in soil $\mathrm{pH}$, OC and $\mathrm{CEC}$ at 3 months of mulch application. Despite, soil nitrogen content was significantly lower in polythene mulch treatment than the control treatment at three months of mulch application (Table 3).

Table 3. Soil parameters observed in different treatments at 3 months and 1 year after mulching.

\begin{tabular}{|c|c|c|c|c|c|}
\hline Stage & Soil parameter & T1 control & T2 oil palm EFB & T3 shade net & T4polythene \\
\hline \multirow{4}{*}{3 months after mulching } & $\mathrm{pH}$ & $5.35^{\mathrm{a}}$ & $5.17^{\mathrm{a}}$ & $5.51^{\mathrm{a}}$ & $5.04^{\mathrm{a}}$ \\
\hline & $\mathrm{N}$ content $(\%)$ & $0.69^{\mathrm{a}}$ & $0.58^{\mathrm{ab}}$ & $0.63^{\mathrm{ab}}$ & $0.57^{\mathrm{b}}$ \\
\hline & $\mathrm{OC}(\%)$ & $2.00^{\mathrm{a}}$ & $2.55^{\mathrm{a}}$ & $2.71^{\mathrm{a}}$ & $2.47^{\mathrm{a}}$ \\
\hline & $\mathrm{CEC}(\mathrm{cmol} / \mathrm{kg})$ & $6.31^{\mathrm{a}}$ & $5.67^{\mathrm{a}}$ & $6.88^{\mathrm{a}}$ & $7.02^{\mathrm{a}}$ \\
\hline \multirow{3}{*}{1 year after mulching } & $\mathrm{pH}$ & $5.74^{\mathrm{a}}$ & $5.54^{\mathrm{a}}$ & $5.64^{\mathrm{a}}$ & $5.57^{\mathrm{a}}$ \\
\hline & $\mathrm{N}$ content $(\%)$ & $0.66^{\mathrm{a}}$ & $0.81^{\mathrm{a}}$ & $0.91^{\mathrm{a}}$ & $0.69^{\mathrm{a}}$ \\
\hline & OC (\%) & $1.92^{\mathrm{b}}$ & $1.95^{\mathrm{ab}}$ & $2.19^{\mathrm{a}}$ & $2.21^{\mathrm{a}}$ \\
\hline
\end{tabular}

Means with the same superscript letter in each row under each stage are not significantly different at $\mathrm{p}<0.05$.

Cuello et al., [18] reported that plastic film mulching increased nitrous oxide gas emission. The lower $\mathrm{N}$ content recorded in the soil under polythene mulch treatment at 3 months after treatment of the current study can be attributed to such $\mathrm{N}$ loss. However, there was no significant difference in soil nitrogen content among all the treatments including the control at one year after mulch application. Farmer et al., [19] investigated long term effects of plastic film mulching on bacterial communities and reported that film mulching and manure fertilization significantly increased the relative abundances of soil bacterial groups such as
Proteobacteria, Bacteroidetes, Actinobacteria, Acidobacteria, Firmicutes, Planctomycetes, Gemmatimonadetes, Verrucomicrobia, Chloroflexi and Cyanobacteria. Therefore, it can be suggested that lower $\mathrm{N}$ content recorded under polythene mulch at three months stage could be remediated by increased bacterial activities in long term. On the other hand, polythene mulch cover might have caused for reduction of fertilizer loss by leaching and contributed for the increase in total nitrogen content. The organic carbon percentage was significantly greater in all the treatments than the control at one year after mulch application but 
the $\mathrm{pH}$ and CEC were not significantly affected by the mulching. Saroa and Lal, [20] and Khurshid et al., [21] concluded that organic matter was significantly higher when mulch was applied compared to the control treatment with no mulch. Enhanced organic carbon content can be attributed to reductions in soil erosion, nutrient leaching and weed competition resulted by the mulch cover. It could be suggested that shade net, polythene and Oil palm EFB mulch would be a good solution for weed control under prevailing labor shortage condition in rubber plantations.

\section{Conclusion}

Weeds in immature rubber plantations could be effectively controlled by mulching with shade net and polythene (by 100\% during the experimental period) and oil palm EFB (by $100 \%$ about 3 months period). There were significant reductions of labor (more than $43 \%$ ) in all three mulching treatments.

\section{Acknowledgements}

The authors acknowledge Biometry Unit of Rubber Research Institute of Sri Lanka for the support given in data analysis. The staff of the Soils and Plant Nutrition Department, Rubber Research Institute of Sri Lanka is also acknowledged for their assistance. Lab attendant, Mr. Sisira Vithana is specially acknowledged for the support given in the field.

\section{References}

[1] Anderson, C., Stryhn, H. and Streibig J. C., (1996). Decline of the flora in the Danish arable fields. Journal of Applied Ecology, 33 (3), 619-626.

[2] Johnson, W. G., Davis, V. M., Kruger, G. R. and Weller, S. C. (2009) Influence of glyphosate-resistant cropping systems on weed species shifts and glyphosate resistant weed populations. European. Journal of. Agronomy, 31, 162-172.

[3] Anon, (2013) Fertilizer to rubber, Advisory Circular No. 2013/04. Rubber Research Institute of Sri Lanka, 2-3.

[4] Shah, P., Dahal, K. R., Shah, S. K. and Dangol, D. R. (2011). Weed proliferation as affected by long-term tillage, mulch and time of nitrogen application in wheat (Triticum aestivum L.). International Research Journal of Appllied and Basic Sciences, $2(2), 65-72$.

[5] Merwin, I. A., Rosenberger, D. A., Engle, C. A., Rist, D. L. and Fargione, M. (1995). Comparing mulches, herbicides and cultivation as orchard groundcover management systems. Hort Technology, 5, 151-158.

[6] Sarolia, D. K. and Bhardwaj, R. L. (2012). Effect of Mulching On Crop Production under Rainfed Condition: A Review. International Journal of Research in Chemistry and Environment 2 (2), 8-20.

[7] Haapala, T., Palonen, P., Korpela A. and Ahokas, J. (2014). Feasibility of paper mulches in crop production: A review. Agricultural and Food Science, 23, 60-79.

[8] Bhardwaj, R. L., Meena, C. B., Singh, N., Ojha, S. N. and
Dadhich, S. K. (2011). Annual progress report of Krishi Vigyan Kendr. Sirohi, MPUAT Udaipur, 45-46.

[9] Das, D. K., Choudhury, D. C., Ghosh, A., Mallikarjuna, B., Suryanarayana, N. and Sengupta, K. (1990). Effect of green manuring, dry weed and black polythene mulching on soil moisture conservation, growth and yield of mulberry and their economics under rainfed condition. Indian Journal of Sericulture, 20, 263-272.

[10] Purohit, K. M., Ray, D. and Subbarao, G. (1990). Effect of mulches on soil temperature, soil moisture, growth and yield of mulberry during winter and rainfed condition in West Bengal. Indian J Sericulture, 29, 64-71.

[11] Bhardwaj, R. L. (2013). Effect of mulching on crop production under rainfed condition - A review. Agricultural Reviews, 34, (3), 188-197.

[12] Shuit, S. H., Tan, K. T., Lee, K. T. and Kamaruddin, A. H. (2009). Oil palm biomass as a sustainable energy source: A Malaysian case study. Energy, 34 (9), 1225-1235.

[13] Kavitha, B., Rajannan, G. and Jothimani, P. (2013). Compost maturity test for empty fruit bunch of palm oil industry solid waste. Scholars Academic Journal of Bioscience, 1 (3), 98101.

[14] Alam, M. Z., Mamun, A. A., Qudsieh, I. Y., Muyibi, S. A., Salleh, H. M. and Omar, N. M. (2009). Solid state biodegradation of oil palm empty fruit bunches for cellulase enzyme production using a rotary drum bioreactor. Biochemical Engineering Journal, 46, 61-64.

[15] Misson, M., Haron, R., Kamaroddin, M. F. A. and Amin, N. A. S. (2009). Pre-treatment of empty palm fruit bunch for production of chemicals via catalytic pyrolysis. Bioresource Technology, 100, 2867-2873.

[16] Bremner, J. M and Breitenbeck, G. A. (1983). A simple method for determination of ammonium in semimicro-Kjeldahl analysis of soils and plant materials using a block digester. Communications in Soil Science and Plant Analysis 14 (10), 905-913.

[17] Nelson, D. W. and Sommers, L. E. (1982). Total carbon, organic carbon and organic matter. In: Page AL (ed) Methods of soil analysis Part 2. Agronomy Monographs 9. ASA and SSSA, Madison. WI. 539-579.

[18] Cuello, J. P., Hwang, H. Y., Gutierrez J. and Pil S. Y. (2015). Impact of plastic film mulching on increasing greenhouse gas emissions in temperate upland soil during maize cultivation. Applied Soil Ecology, 91, 48-57.

[19] Farmer, J., Zhang, B., Jin, X. and Wang, J. (2017). Long-term effect of plastic film mulching and fertilization on bacterial communities in a brown soil revealed by high through-put sequencing. Archives of Agronomy and Soil Science, 63 (2), 230-241.

[20] Saroa, G. S. and Lal, R. (2003). Soil restorative effects of mulching on aggregation and carbon sequestration in a Miamian soil in Central Ohio. Land Degradation and Development, 14, 481-493.

[21] Khurshid, K., Iqbal, M., Arif, M. S. and Nawaz, A. (2006). Effect of tillage and mulch on soil physical properties and growth of maize. International Journal of Agriculture and Biology, 8, 593-596. 